\title{
A SOFTWARE TOOL TO SUPPORT THE SELECTION OF CANDIDATES IN PRIVATE SECURITY SERVICES
}

Nowadays the protection of life, health and property of individuals is in the centre of public interest. There is not a distinction between the provision of such protection by private or public sector. The private security services play an important role in protection of persons and property. The subjects of protection are not only people and property, but also sensitive information which is relevant for the state interest or business entities. Based on research, the private security services do not make a selection of employees systematically. One of the reasons is the absence of an analysis of candidates' personal competencies which should take into account the requirements of the protected subject. The aim of the article is therefore a software solution for modelling the personal competencies of applicants for the job in private security services.

Keywords: security services, selection of employees, software

\section{Introduction}

The problem of selection of security service employees and their competencies is solved by the project research team (employees of the Faculty of Security Engineering and Faculty of Management Science and Informatics) in the project „Optimisation of the competencies in correlation with the particularity of the type positions in security services" (VEGA $1 / 0064 / 15)$. The main goal of the project is to create a tool enabling modelling of the personal competencies of the applicants for private security services depending on requirements of the security environment and protected interest. The software tool is created in the conditions of the Slovak Republic, in Slovak language, and it consists of adatabase system and aweb application.

Private security in Slovakia operates as a private security service and technical service to protect persons and property. Requirements for running a security service (professional, physical and mental) are stated in the Directives [1], [2]:

- Act No. 473/2005 Coll. On providing services in the field of private security and on modification and amendment of certain Acts,

- Regulation of the Ministry of Internal Affairs No. 634/2005 Coll., which is used to implement the provisions of the Act No. 473/2005 Coll. On providing services in the field of private security and on modification and amendment of certain Acts
In the Act on providing services in the field of private security (Act No. 473/2005 Coll.), system requirements in terms of the qualification of private security service providers are not specified. Guard duty and detective services are considered the same. Fundamental differences in the subject matter, personnel competencies and expertise are not respected. The Act demoted the more demanding detective service to the level of the standard physical protection (e.g. qualification requirements, professional knowledge, general eligibility). Hereby the system of personnel selection and educational preparation of the detective service providers is depreciated.

\section{Selection of security staff}

The selection and recruitment of new employees is a significant step for an organization and can be understood as an investment into its development. Even the process of employee selection for private security service providers is quite problematic. Nevertheless, there is an effort to identify basic competence requirements for some type positions, which can be evaluated positively (National Occupation System http://www. sustavapovolani.sk). Based on theoretical knowledge, surveys and practical experience, an algorithm for the selection of security staff was created. This algorithm contains the following subsequent steps [3]:

\footnotetext{
* ${ }^{1}$ Valeria Moricova, ${ }^{2}$ Monika Vaclavkova, ${ }^{1}$ Jana Studena, ${ }^{3}$ Bo Wang

${ }^{1}$ Faculty of Security Engineering, University of Zilina, Slovakia

${ }^{2}$ Faculty of Management Science and Informatics, University of Zilina, Slovakia

${ }^{3}$ Ningbo University Of Technology, China

E-mail valeria.moricova@fbi.uniza.sk
} 
Preliminary phase:

a) Job analysis;

- Security analysis of an object and its environment:

- Job description;

- Job specification;

b) Defining the suitability of employees;

c) Recruitment.

Selection phase:

a) Examining a structured Curriculum Vitae and a personal questionnaire;

b) Preliminary (initial) interview;

c) Testing the applicants;

d) Selective (continuous) interview;

e) Examining references.

Evaluation phase:

a) Selection assessment;

b) Selective (final) interview;

c) Decision on applicant selection;

d) Informing the applicant of the selection.

Using the above algorithm, for the needs of the National System of Professions by the expert group of the Slovak Chamber of Private Security, 10 type positions were updated and 6 type positions were newly established [3]: Manager in the field of guard and detective services and self-protection; Project Specialist in the field of private security; Lecturer in the field of security services; Detective Specialist; Trainee Detective; Chief Detective.

Subsequently, private security staff files were created for all type positions. Each file contains the characteristics of a type position, a job description, occupational regulation, the ISCO-08 and ISCO-08 specification as well as the required level of education in terms of the European Qualifications Framework and the National Qualifications Framework. The file also lists the general capabilities, expertise, and skills that an ideal security employee should have. For a particular type position, the preferred level of the selected general competencies (elementary, advanced, high) and the Head of Physical Protection Change level of the qualification framework (professional knowledge and skills) are assigned. The defined requirements were the starting point for creating a software tool to support personnel selection in security services.

\section{Software tool to support personnel selection in the security services}

Information systems are an inseparable part of human activity in nearly all fields [4]. For example, in the field of Crisis Management, it is obvious that the management of crisis situations is undergoing rapid changes due to advances in Information Technology. After over three decades of application of computer based information systems to the crisis management, these systems are getting wider acceptance by the community of emergency managers [5]. In the field of Security Management, various supportive software tools are more and more frequently used [6].

Firms engaged in security services such as Private Security Service (further SBS) also belong to the field of security technologies. Within the optimisation of SBS services in the Slovak Republic, there is an effort to deal with the competencies of the hired employees. To simplify the activities connected with the mentioned problem, within the project VEGA 1/0064/15 supportive software tool was designed and implemented. Figure 1 depicts the data model of the designed software tool database.

\section{Development of the software tool database}

When developing software systems, it is necessary to set basic system requirements at the beginning. That is why the very first step of the software tool creation was defining requirements for the functionality of the respective tool.

Since the experts from various fields take part in the project, it was necessary to create a set of requirements, so that it would suit the needs of the experts from the security management and psychology. At the same time, it was necessary to specify the requirements, so that it would also follow the needs and suggestions of the experts from the field of informatics. Therefore, the initial phase of the project included several project team member meetings to specify the requirements.

The basic part of the tool is the database of individual type positions as well as the database of all attributes, specifics and characteristics of individual type positions. Based on the Act No. 473/2005 Coll., which puts emphasis on integrity, reliability, health and required professional eligibility of the employees of SBS, the basic structure of the database was created. The second source of creating the basic structure of the database was the register of occupations of the National Occupation System - area SBS. The two respective sources formed the part of the database which was named legal requirements. Requirements of this part of the database are necessary for the creation of the software tool as early as the first step of its implementation.

The second group of requirements for the data and the database were the specifics of individual objects from the point of view of risk analysis. To be more precise, it is the specification of inner and outer security risks, sources of danger in the respective object and the whole of the situation from inner or outer point of view in the respective object where the type position will be carried out. The methods and forms of protection required in the respective object will result from identified security risks and dangers. These methods and forms will then indicate certain supplementary requirements for the corresponding type positions. This part of the database was named specific requirements. The listed group of requirements is currently in the process of extension and will be implemented in the near future. Within the 


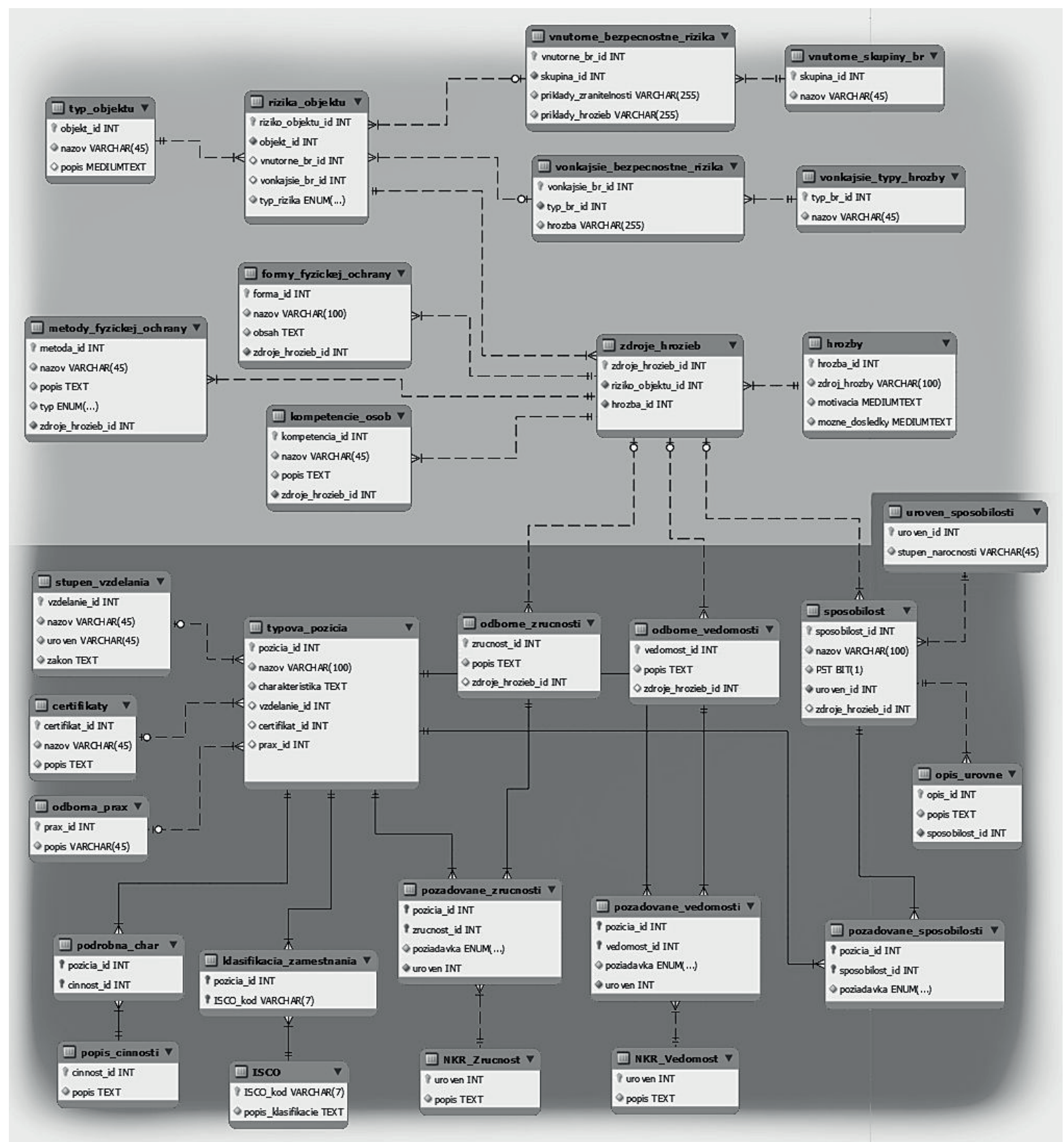

Figure 1 Data model of the database of the designed software tool - see Annex for English equivalents of the tokens and collocates

project, our goal was to take into account all the requirements, the legal group as well as the group of specific requirements. However, the project had limited human and time capacities and that is why, in the first phase, our attention was focused on the group of legal requirements.

The database of the software tool consists of data of various nature and in the present, the most appropriate tool to accomplish this task is the relational database system. Before developing the database, it was necessary to design its structure by the means of the data model. The development of the data model underwent several phases of modification and, as a result, several alternatives were created. The eventual alternative consisted of 29 database tables so this data model can be considered large.

Based on the data model, the database system which enables administration of individual dials in the database was developed. The database system MySQL is the system in which the database is implemented. This system is at the moment the most popular and freely spreadable from all SQL systems in the field of 


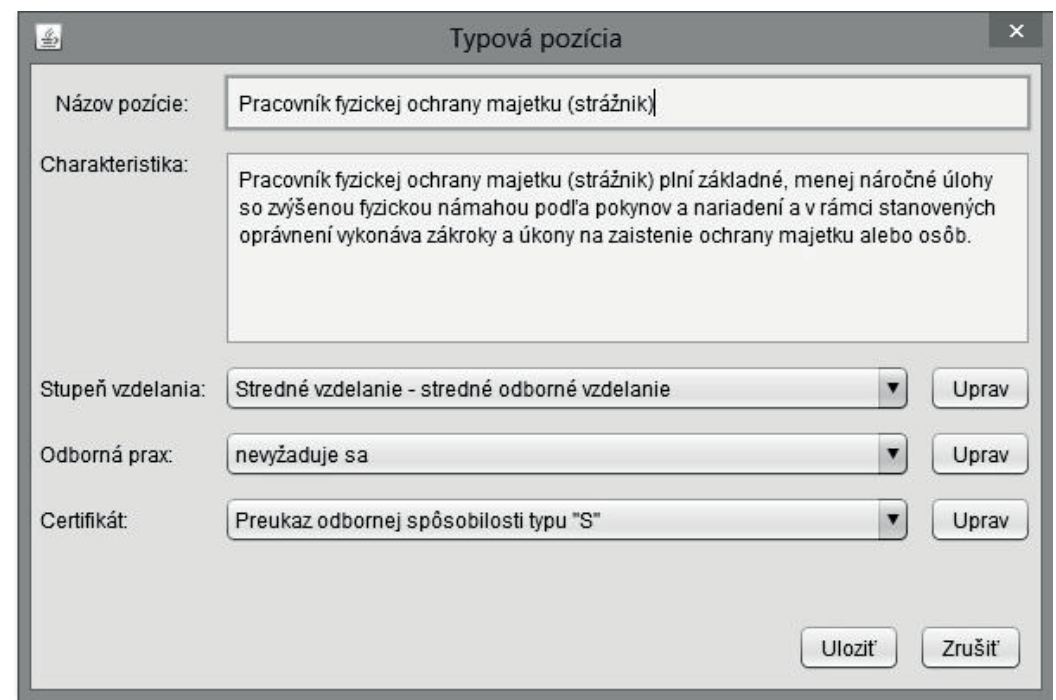

Figure 2 Form for modifying the type position - see Annex for English equivalents of the tokens and collocates

the database administration. It is developed, distributed and supported by Oracle Corporation. When developing the database, the tool MySQL Workbench was used, which is the graphic tool for the work with MySQL servers and databases. It fully supports MySQL Server, versions 5.1 and higher. It is compatible with MySQL Server 5.0, but it does not support all its functions. It is not compatible with MySQL Server, versions 4.X.

For developing the application of the database system working over the database, the programming language Java was selected. Java is an object oriented programming language, originally created by Sun Microsystems. The advantage of the language Java is that the source codes are independent from the computer architecture and they can be activated on any device which has virtual Java machine (JVM) available.

The environment that was used when developing the respective application was the environment of NetBeans which currently is one of the most used development environments. NetBeans is officially the development environment for Java 8 . It is a simple tool for development of Java desktop, mobile and web applications, but also HTML5 applications with HTML, JavaScript and CSS. The main advantage of the NetBeans environment compared to other rival environments is the fast development of user interface, which is enabled by the graphic editor with a drag-and-drop tool.

When developing the database system, the technology Hibernate was used and it is one of the fastest developing information system technologies. The Hibernate ORM is an object-relational mapping framework for the Java language. Its main task is to map Java classes to database tables and data of Java types to SQL data types.

In Figure 2, there is one of the forms for editing the database, to be more specific, for editing the type position and its attributes.
The respective form is connected with other forms, so that it copies the relations among individual dials in the database.

The database system was designed as a part of a software tool unit in the form of one common component. The database system enables creation of new items in the database, removal of unnecessary items as well as the change of desired items. The database system was tested at the Faculty of Security Engineering, University of Zilina (further FSE) and the verification was successful. The database system will be placed on the FSE server and it will be administered by an administrator (the main administrator/administrator) to prevent changes in the system by any of the users. The administrator will have an authorization for editing the database entries and will become the database manager.

\section{Completion of other parts of the software tool}

After developing the database, it was necessary to create an application for other users of the software tool. Since in our conditions it is a standard to expect a common user to be able to operate web browsers and web applications, the next part of the software unit was designed as a web application. The advantage of such application is that the website is accessible to a wide range of users without necessity of further installation of a new application to the personal computer, whereby it is accessible for various devices with the Internet access. Nowadays, the web applications are a growing trend in the field of IT technologies.

Initially, the application was implemented for the part of the database which deals with legal requirements. In the near future, the web application will be extended with the definition of requirements, placed in the group of specific requirements. 

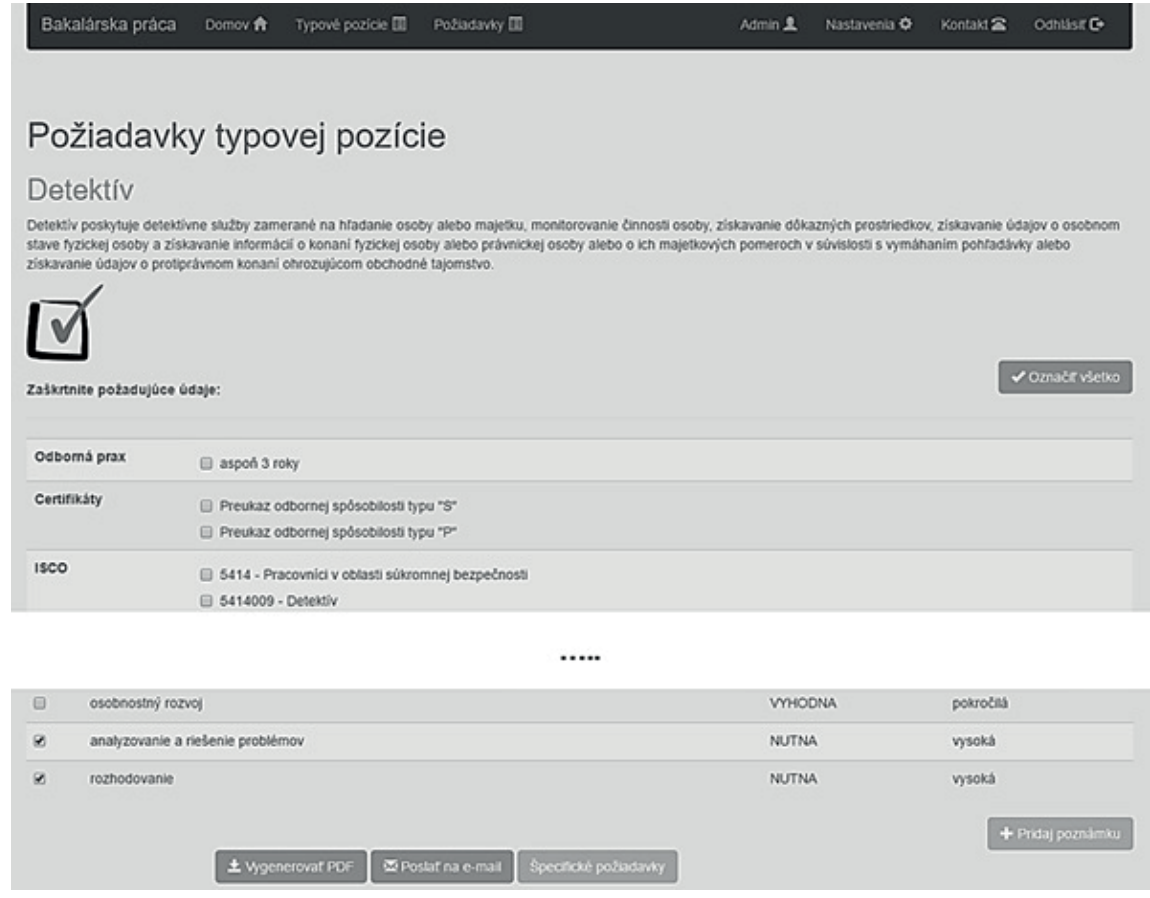

Figure 3 Part of the form for creating a file with the requirements for the type position - see Annex for English equivalents of the tokens and collocates

There are various different methods how to create a web application. In our project, the most common and the most popular type of web application architecture - Model - View Controller (MVC) was used. The basic idea of MCV architecture is to detach the application logic from the presentation logic. This is the reason why the application is so well-arranged. It is divided into three components: Model, View, Controller. These components are presented as separate classes apart from the View component.

For back-end (the server part), PHP script language was selected, which is widely used for creating the dynamic web applications, specifically open source PHP framework CodeIgniter with the utilization of HTML5, CSS3, JS and library jQuery. In terms of front-end (the client part), Bootstrap was applied, which is HTLM, CSS and JS framework creating responsive applications on the Web.

The web application again copies the strategy of the database part, so that it enables the work of users on three different levels:

- common user can use the limited number of operations which he/she can conduct,

- administrator can implement changes in the data,

- main administrator can manage the administration rights for the common administrator.

Potential users of the web application are personnel managers in security services (common users).

After loading the website, in the window of the browser, the registration window with the possibility of authentication will display. After filling in the respective form, the user will be sent the file with the registration data.

If the user clicks on the icon "type positions“, the list of 16 type positions identified within security services in the National Occupation System will display. Each type position is described and there is also an icon of magnifier. The icon of magnifier enables the user to display the form with respective requirements for the selected type position. The form is quite large.

For each item, which defines the category of requirements for the selected type position, the title of the specific item is stated as well as respective options of particular requirements. With each requirement, there is a tick window which the user can mark. In the top right corner of the form, the user can mark all the requirements for the selected type position at once. In the right part under the last requirement, most of the requirement categories feature the option to add a note where the user can complete his/her notes, but also various additional specific requirements for the selected type position, which are not available in the database. If the user wants to create a file with selected requirements, he/she can do so in the bottom part of the window where there is a possibility to generate a file on the disc, which will encompass all the selected requirements according to the categories, in the PDF format. The second possibility is to have the respective file sent to the email address stated in the data.

Due to the form size, in Figure 3 only a part of the displayed field is presented. It is only one category of requirements. Further categories in the system are selected in a similar way, as in Figure 3. 
The user with the authorization of the administrator or the main administrator has besides the stated possibilities also the right to conduct activities linked with editing specific items in the database. He/she can modify the list of requirements in some of the categories of requirements for specific type positions. Apart from this, administrators are responsible for delegating or taking away the authorization of a common user, as well as the administration of user accounts.

The process of selecting the most suitable job applicant can be supported by several methods of multi-criteria decision-making, e.g. Analytical Hierarchy Process (AHP), Decision Matrix Method (DMM), Forced Decision Matrix Method (FDMM), Potentially All Pairwise Rankings of All Possible Alternatives (PAPRIKA). An automated selection of candidates using the above methods may be an extension of the proposed software.

\section{Conclusion}

The solution of security problems and crises is influenced by various factors. The most significant features of crises are the lack of time and information, which puts a lot of pressure on the employees. These requirements on preparation of individuals for specific type positions are increasing. Itis the reason why the level of competencies required from employees of security services is also increasing, proportionally to their work activities [7], [8].

Creation of the software tool to support the selection of employees in security services was a part of the solution of the project VEGA $1 / 0064 / 15$ for optimisation of competencies for type positions in SBS. A supportive software tool consisting of more components - modules, which were implemented with the use of current modern technologies, was developed. The created tool is easy to use and, supposedly, the users will not have problems to learn to operate it. In the first phase of the task solution, dials for the database system were prepared, even for specific requirements. However, because of the capacity of the project personnel as well as because of the project time horizon only legal requirements were included in the web part of the implemented software tool. Currently, an analysis of the specific requirements is being conducted, plan to include it in the advanced web application.

Due to the above mentioned reasons, the designed software tool has some limits. At the moment, the tool is available to specific SBS users so they can test it and comment on possible improvements. After delivering the comments in the form of a test protocol, the tool will be adjusted to the needs of the users. However, even the current solution can, when being correctly used, simplify the work of selection of employees for type positions in security services.

\section{Acknowledgements}

This work is supported by grant VEGA $1 / 0064 / 15$ named "Optimisation of the competencies in correlation with the particularity of the type positions in security services”.

\section{References}

[1] Act No. 473/2005 Collection of Laws about Providing Services in the Field of Private Security and about Modification and Amendment of Some Laws [online]. 2017. Available: http://www.noveaspi.sk/products/lawText/1/60783/1/2 [accessed: 2017-09-02].

[2] Regulation of the Ministry of Internal Affairs SR No. 634/2005 Collection of Laws, which is Used to Implement the Provisions of the Law No. 473/2005 Collection of Laws about Providing Services in the Field of Private Security and about Modification and Amendment of Some Laws [online]. 2017. Available: http://www.noveaspi.sk/products/lawText/1/60948/1/2 [accessed: 2017-09-02].

[3] VIDRIKOVA, D., BOC, K.: Personnel Aspects of Selecting Human Resources for Private Security Services. University of Zilina, Zilina, p. 237, 2014.

[4] REITSPIS, J., MESAROS, M., BARTLOVA, I., CAHOJOVA, L., HOFREITER, L., SELINGER, P.: Management of Security Risks. EDIS, Zilina, 2004.

[5] RISTVEJ, J., ZAGORECKI, A.: Information Systems for Crisis Management - Current Applications and Future Directions. Communications - Scientific Letters of the University of Zilina. 13(2), 59-63, 2011.

[6] RISTVEJ, J., LOVECEK, T.: Software Products for Risk Assessment. Mathematical Methods and Techniques in Engineering \& Environmental Science, Proceedings of 4th WSEAS International Conference on Natural Hazards (NAHA '11), Italy, 198-203, 2011.

[7] LOVECEK, T., RISTVEJ, J., SVENTEKOVA, E., SISER, A., VELAS, A.: Currently Required Competencies of Crisis and Security Managers and New Tool for Their Acquirement. Management Innovation and Business Innovation, Proceedings of 3rd International Conference on Management Innovation and Business, Philippines, 3-8, 2016.

[8] TITKO, M., ZAGORECKI, A.: Modelling Vulnerability of Transportation Network Using Influence Diagrams. Communications Scientific Letters of the University of Zilina, 15(4), 97-100, 2013. 


\section{Annex for English equivalents of the tokens and collocates}

Table A1 English equivalents figure 1 Data model of the database of the designed software tool

\begin{tabular}{|c|c|}
\hline Slovak terms & English equivalent \\
\hline Typ objektu & Object type \\
\hline Riziko objektu & Facility risk \\
\hline Vnutorne bezpecnostne rizika & Internal security risks \\
\hline Vonkajsie bezpecnostne rizika & External security risks \\
\hline Vnutorne skupiny & Inner groups \\
\hline Vonkajsie typy hrozby & External types of threat \\
\hline Metody fyzickej ochrany & Physical protection methods \\
\hline Formy fyzickej ochrany & Forms of physical protection \\
\hline Kompetencie osôb & Competence of persons \\
\hline Zdroje hrozieb & Threat sources \\
\hline Hrozby & Threats \\
\hline Stupen vzdelania & Level of education \\
\hline Certifikaty & Certificates \\
\hline Odborna prax & Professional experience \\
\hline Typova pozicia & Type position \\
\hline Odborne zrucnosti & Professional skills \\
\hline Odborne vedomosti & Professional knowledge \\
\hline Spôsobilost & Competence \\
\hline Uroven spôsobilosti & Level of competence \\
\hline Opis urovne & Description of the level \\
\hline Podrobna charakteristika & Detailed characteristics \\
\hline Popis cinnosti & Activity description \\
\hline Klasifikacia zamestnania & Job classification \\
\hline Pozadovane zrucnosti & Required skills \\
\hline Pozadovane vedomosti & Required knowledge \\
\hline Pozadovane spôsobilosti & Required competences \\
\hline
\end{tabular}

Table A2 English equivalents figure 2 Form for modifying the type position

\begin{tabular}{ll}
\hline Slovak terms & English equivalent \\
\hline Typova pozicia & Type position \\
Nazov pozicie: Pracovnik fyzickej ochrany majetku (straznik) & Job Title: Physical Property Protection Officer (Guardian) \\
$\begin{array}{l}\text { Charakteristika: Pracovnik fyzickej ochrany majetku (straznik) } \\
\text { plni zakladne, menej narocne ulohy so zvysenou fyzickou }\end{array}$ & basic, less demanding tasks with increased physical effort according to instructions \\
namahou podla pokynov a nariadeni a v ramci stanovenych & and regulations and, under authorization, performs interventions and actions to \\
opravneni vykonava zakroky a ukony na zaistenie ochrany & ensure the protection of property or persons. \\
majetku alebo osôb. & \\
Stupen vzdelania: Stredne vzdelanie - stredne odborne vzdelanie & Level of education: Secondary education - secondary vocational education \\
Odborna prax: nevyzaduje sa & Professional experience: not required \\
Certifikat: Preukaz odbornej spôsobilosti typu "S” & Certificate: Professional license type "S” \\
Uprav & Edit \\
Ulozit & Save \\
Zrusit & Cancel
\end{tabular}


Table A3 English equivalents figure 3 Part of the form for creating a file with the requirements for the type position

\begin{tabular}{|c|c|}
\hline Slovak terms & English equivalent \\
\hline Poziadavky typovej pozicie & Type position requirements \\
\hline Detektiv & Detective \\
\hline $\begin{array}{l}\text { Detektiv poskytuje detektivne sluzby zamerane na hladanie osoby } \\
\text { alebo majetku, monitorovanie cinnosti osoby, ziskavanie dôkaznych } \\
\text { prostriedkov, ziskavanie udajov o osobnom stave fyzickej osoby } \\
\text { a ziskavanie informacii o konani fyzickej osoby alebo pravnickej osoby } \\
\text { alebo o ich majetkovych pomeroch v suvislosti s vymahanim pohladavky } \\
\text { alebo ziskavanie udajov o protipravnom konani ohrozujucom obchodne }\end{array}$ & $\begin{array}{l}\text { The detective provides detective services: to search for a person or } \\
\text { property, to monitor the activity of a person, to obtain evidence, to obtain } \\
\text { data on the physical condition of a natural person, to obtain information } \\
\text { on the conduct of a natural person or a legal person or on their assets } \\
\text { in connection with recovery or collection of data on unlawful conduct } \\
\text { threatening business secrets. }\end{array}$ \\
\hline
\end{tabular}
tajomstvo.

Odborna prax: aspon 3 roky

Certifikaty: Preukaz odbornej spôsobilosti typu "S" / Preukaz odbornej spôsobilosti typu "P"

Pracovnici v oblasti sukromnej bezpecnosti

Osobnostny rozvoj

Analyzovanie a riesenie problemov

Rozhodovanie

Vyhodna

Nutna

Pokrocila

Vysoka

Oznacit vsetko

Pridat poznamku

Vygenerovat PDF

Poslat na e-mail
Professional experience: at least 3 years

Certificates: Professional license type "S" / Professional license type "P"

Workers in the field of private security

Personality development

Analyzing and solving problems

Decision making

Advantageous

Necessary

Advanced

High

Mark everything

Add note

Generate PDF

Send to e-mail 